\title{
Union membership and density: Some (not so) stylized facts and challenges
}

European Journal of Industrial Relations 19(3) 255-272

(C) The Author(s) 2013

Reprints and permissions: sagepub.co.uk/journalsPermissions.nav DOI: 10.1 I77/0959680I। 3493373 ejd.sagepub.com

\section{Claus Schnabel}

Universität Erlangen-Nürnberg, Germany

\begin{abstract}
This article surveys recent data and empirical literature on (trends in) unionization and its determinants in advanced countries. There are some robust stylized facts, for instance that unionization is positively related to public sector employment, establishment size, and the business cycle. Union-administered unemployment insurance and union presence at the workplace also play a positive role. However, some seemingly obvious explanations for union decline - such as economic globalization and changes in economic structure and workforce composition - do not seem to have impeded union membership everywhere; nor has the decentralization of collective bargaining. It also remains an open question whether changes in social values and employee attitudes towards unions have affected unionization negatively.
\end{abstract}

\section{Keywords}

trade unions, union density, union membership, unionization

\section{Introduction}

In the 20th century, trade unions became important labour market and political actors in most industrialized countries. In the 21 st century, however, some observers argue that 'organised labour seems heading for extinction' (The Economist, 21 September 2006). Since unions' existence and influence depend on their ability to attract and nurture a loyal membership, it is important to know which factors determine the extent and stability of unionization.

Although the economic, sociological and political science literature contains a reasonable amount of theoretical and empirical work on unions and their membership, relatively few stylized facts have emerged and some of these are not so stylized and robust at all. In particular, some popular perceptions - for example, that union decline is ubiquitous, that unions cannot adjust to structural changes in the economy, that some groups

\section{Corresponding author:}

Claus Schnabel, Universität Erlangen-Nürnberg, Lange Gasse 20, 90403 Nürnberg, Germany.

Email: claus.schnabel@wiso.uni-erlangen.de 
in the workforce simply do not unionize, and that unions are victims of globalization are highly questionable. By surveying recent empirical studies from various disciplines on unionization in (mostly) Western countries, this article attempts to provide a clearer picture of what we know (and do not know) about union membership and density.

The focus is on empirical regularities and stylized facts. These can often be related to theoretical considerations from various disciplines, though usually not unambiguously (Ebbinghaus et al., 2011; Schnabel, 2003). Tests of theoretical explanations have proved difficult, and empirical studies usually take an eclectic approach combining economic as well as socio-political considerations. Most empirical analyses of unionization use one (or more) of three approaches (Ebbinghaus and Visser, 1999; Schnabel, 2003). They either stress cyclical explanations and attempt to identify the macro-determinants of union growth and decline by means of time-series studies, or they provide structural explanations and focus on individual characteristics of union (and non-union) members as well as on sectoral and occupational factors, using cross-sectional or panel studies, or they favour institutional explanations and analyse cross-national variations in institutional settings assumed to influence unionization. This distinction will be followed below when discussing the relationships between unionization and the business cycle, structural change, workforce composition and institutional settings. ${ }^{1}$ Since the availability of international (panel) datasets has recently enabled researchers to combine some of these approaches, considerable attention will be given to such international analyses. First, however, an update on the extent and development of unionization in advanced capitalist countries is in order.

\section{Union density: Some data and developments}

Comprehensive data on union membership and density are provided by the ICTWSS Database (Visser, 2011). While these stem from different sources and comparisons across countries should thus be made only cautiously, this is a minor problem when making comparisons over time. Table 1 presents trends in union density (union membership net of those outside the active, dependent and employed labour force as a proportion of wage and salary owners in employment) in countries for which consistent data are available for long time periods. Density has fallen in 24 of 25 countries over the last 20 years and in 23 of 24 countries over the last 30 years (with the notable exceptions of Spain and Finland, respectively). Over the longest possible observation period, 1960 to 2010, density has fallen in 13 out of 18 countries but increased in five countries.

Although a cross-sectional comparison of data that stem from various sources should not be over-interpreted, it is also apparent that density varies substantially across countries. The most recent data for 2009-2010 range from around 70 percent in Finland, Sweden and Denmark to under 12 percent in France, South Korea and the USA. Substantial variation can also be observed in previous years, and the coefficients of variation across countries calculated for these years have tended to increase over time, indicating divergence rather than convergence.

Two stylized facts emerge from this brief analysis. First, density has indeed fallen over the last decades in almost all affluent countries. Second, density and its trends vary considerably across Western countries, with no signs of convergence towards union 
Table I. Union density in 25 advanced countries.

\begin{tabular}{|c|c|c|c|c|c|c|c|c|}
\hline & \multicolumn{6}{|c|}{ Union density (net membership/employment, \%) } & \multicolumn{2}{|c|}{ Change (\% points) } \\
\hline & 1960 & 1970 & 1980 & 1990 & 2000 & 2010 & $1960-2010$ & $01980-2010$ \\
\hline$A U$ & 50.2 & 44.2 & 48.5 & 39.6 & 24.5 & $19.0^{a}$ & -31.2 & -29.5 \\
\hline AT & 67.9 & 62.8 & 56.7 & 46.9 & 36.6 & 28.1 & -39.8 & -28.6 \\
\hline $\mathrm{BE}$ & 41.5 & 42.1 & 54.1 & 53.9 & 49.5 & $52.0 \mathrm{a}$ & 10.5 & -2.1 \\
\hline CA & 29.2 & 31.0 & 34.0 & 34.0 & 30.8 & $30.3^{a}$ & I.I & -3.7 \\
\hline $\mathrm{CH}$ & 36.1 & 28.9 & 27.7 & 22.7 & 20.6 & $17.8^{a}$ & -18.3 & -9.9 \\
\hline $\mathrm{CL}$ & & & & 18.2 & 13.5 & $14.3^{a}$ & & \\
\hline DE & 34.7 & 32.0 & 34.9 & 31.2 & 24.6 & 18.6 & -16.1 & -16.3 \\
\hline DK & 56.9 & 60.3 & 78.6 & 75.3 & 74.2 & $68.8^{a}$ & 11.9 & -9.8 \\
\hline ES & & & 18.7 & 12.5 & 16.7 & $15.9^{a}$ & & -2.8 \\
\hline $\mathrm{FI}$ & 31.9 & 51.3 & 69.4 & 72.5 & 75.0 & 70.0 & 38.1 & 0.6 \\
\hline $\mathrm{FR}$ & 19.6 & 21.7 & 18.3 & 9.9 & 8.0 & $7.6^{b}$ & -12.0 & -10.7 \\
\hline GR & & & 39.0 & 34.1 & 26.5 & $24.0^{b}$ & & -15.0 \\
\hline IE & 50.4 & 59.1 & 63.5 & 56.7 & 40.4 & $36.6^{a}$ & -13.8 & -26.9 \\
\hline IT & 24.7 & 37.0 & 49.6 & 38.8 & 34.8 & 35.1 & 10.5 & -14.4 \\
\hline$J P$ & 32.9 & 35.1 & 31.1 & 26.1 & 21.5 & 18.5 & -14.4 & -12.7 \\
\hline LU & & 46.8 & 50.8 & 46.4 & 42.5 & $37.3^{b}$ & & -13.5 \\
\hline NL & 40.0 & 36.5 & 34.8 & 24.3 & 22.9 & $19.0 \mathrm{a}$ & -21.0 & -15.8 \\
\hline NO & 60.0 & 56.8 & 58.3 & 58.5 & 54.4 & $54.4^{a}$ & -5.6 & -3.9 \\
\hline$N Z$ & & 56.5 & 69.1 & 48.8 & 22.4 & $21.4^{a}$ & & -47.7 \\
\hline PT & 100.0 & 100.0 & 54.8 & 28.0 & 21.6 & 19.3 & -80.7 & -35.5 \\
\hline SE & 72.1 & 67.7 & 78.0 & 81.5 & 80.1 & 68.9 & -3.2 & -9.1 \\
\hline SG & & 25.4 & 22.8 & 14.4 & 16.1 & $17.6^{a}$ & & -5.2 \\
\hline UK & 40.4 & 44.8 & 50.7 & 39.3 & 30.5 & $27.5^{a}$ & -12.9 & -23.2 \\
\hline US & 30.9 & 27.4 & 22.3 & 15.5 & 12.8 & II.4 & -19.5 & -11.0 \\
\hline $\begin{array}{l}\mathrm{cv}^{c}, 18 \text { countries } \\
\mathrm{cv}^{c}, 24 \text { countries }\end{array}$ & 0.426 & 0.396 & $\begin{array}{l}0.367 \\
0.419\end{array}$ & $\begin{array}{l}0.481 \\
0.513\end{array}$ & $\begin{array}{l}0.569 \\
0.596\end{array}$ & $\begin{array}{l}0.596 \\
0.612\end{array}$ & & \\
\hline
\end{tabular}

${ }^{a} 2009 ;{ }^{b}$ 2008; c coefficient of variation.

Source: ICTWSS Database, version 3.0 (Visser, 20I I); own calculations.

decline on an Anglo-Saxon pattern. While these variations have been noted before (Checchi and Lucifora, 2002; Schmitt and Mitukiewicz, 2012; Scruggs, 2002; Visser, 2006), they need to be reiterated since they stand in contrast to conventional wisdom, in particular in Anglo-Saxon countries, that unions are about to become extinct everywhere. Against this background, I turn to international empirical evidence on a range of potential determinants of unionization.

\section{Unionization and the business cycle}

Following influential studies for the USA and other countries by Ashenfelter and Pencavel (1969) and Bain and Elsheikh (1976), numerous time-series models were estimated that try to explain union growth in terms of such components of the business cycle 
as wage and price changes, employment growth, and unemployment (for detailed discussions see the surveys by Riley, 1997 and Schnabel, 2003). In addition to their ad hoc use and justification of explanatory variables, a serious flaw of the older studies in the business cycle approach is their failure to separate cycle and trend. Traditional cyclical models mainly explain the ups and downs of union membership (or density) by corresponding movements in business cycle variables while neglecting shifts in underlying, secular variables which may explain the trend.

Carruth and Disney (1988) were the first to distinguish explicitly between (short-run) cyclical and (long-run) trend factors of unionization in the UK, and in a study for Germany, Carruth and Schnabel (1990) made the first use of co-integration techniques in identifying a long-run equilibrium relationship that can serve as an error-correction mechanism in the dynamic modelling of unionization. Similar empirical approaches with co-integration and error-correction techniques have been undertaken, for example, by van Ours (1992) for the Netherlands, Borland and Ouliaris (1994) for Australia, Checchi and Corneo (2000) for Italy and Checchi and Visser (2005) in a panel study of 14 European countries.

One stylized fact emerging from these studies is that union growth is procyclical. In particular, it appears that employment growth as well as price and/or wage inflation enhances membership growth, at least in the short term. In contrast, a rise in unemployment tends to reduce union growth and density (except in countries with a union-administered unemployment insurance, on which see below). Although estimated speeds of adjustment in many error-correction models are relatively low (Calmfors et al., 2001), in most European countries a return to lower unemployment thus works in the direction of stabilizing union density. This implies that in those countries it might be appropriate for unions to pursue strategies (or not oppose government policies) aimed at preventing or reducing unemployment.

\section{Unionization and structural change}

It is often argued that union growth and decline are influenced by secular trends that change the industrial structure from high- to low-unionized sectors and workplaces (Polachek, 2004). Examples are the shift in employment from manufacturing to private services, the reduction in average firm size that often goes with this and the changing importance of public sector employment. A closer look at the empirical evidence, however, reveals that purely sectoral explanations of union decline are too narrow.

Some international studies for groups of countries find that a shift in employment from manufacturing (the traditional union stronghold) to the service sector with lower union density (Blaschke, 2000; Lee, 2005; Polachek, 2004). Other studies report insignificant effects (Brady, 2007) or varying effects depending on the specification and the size of the sample used (Calmfors et al., 2001). The empirical evidence from individual country studies is equally mixed. While some studies indicate the relevance of structural changes (Carruth and Schnabel, 1990 for Germany; Farber and Western, 2001 for the USA), many studies demonstrate that the impact of sectoral changes on union density is marginal (Blanchflower and Bryson, 2009 for the UK; Charlwood and Haynes, 2008 for 
New Zealand; Checchi and Corneo, 2000 for Italy; Fitzenberger et al., 2011 for Germany; van Ours, 1992 for the Netherlands).

Parallel to the decline of large manufacturing workplaces, changes in the size of workplaces reflecting changes in the organizational structure of production have become important. The probability of unionization is usually expected to rise with establishment size because union costs of organizing should be lower in larger units, and union services may be valued most highly in large, bureaucratic organizations where workers are likely to be treated impersonally and feel a greater need (or higher peer pressure) for representation (Riley, 1997; Schnabel, 2003). The empirical evidence clearly supports such a positive relationship. Studies using data on individuals from a wide range of countries included in the European Social Survey (ESS) find a positive correlation between establishment size and the probability of union membership when pooling across countries (Ebbinghaus et al., 2011; Kirmanoğlu and Başlevent, 2012) as well as in the majority of countries analysed separately (Schnabel and Wagner, 2007). Studies for individual countries also tend to show that unionization is more likely in larger establishments (for instance, Bain and Elias, 1985 for the UK; Biebeler and Lesch, 2007 for Germany; van den Berg and Groot, 1992 for the Netherlands). Since these studies are all cross-sectional, it is reassuring that a panel study for Germany by Fitzenberger et al. (2011) also finds a substantial positive impact of firm size on unionization. This suggests that the decline in average firm size observed in many countries tends to weaken unionization.

The empirical evidence is also quite clear-cut concerning the role of the public sector, where union organizing is said to be much easier because of lower recruitment costs in large homogeneous organizations with low turnover rates and low employer hostility towards unionism (Schnabel, 2003). Descriptive evidence provided by Ebbinghaus (2006) and Visser (2006) makes clear that in all countries analysed, union density is considerably higher in the public than in the private sector. With one exception (Calmfors et al., 2001), the panel studies for groups of countries which have included this variable report that a higher share of public employment is associated with higher union density (Blaschke, 2000; Checchi and Lucifora, 2002; Checchi and Visser, 2005; Scruggs and Lange, 2002; Visser, 2002). A positive relationship between public employment and unionization is also found in most cross-sectional studies for countries like the UK, the USA and Canada (Blanchflower, 2007), Germany (Schnabel and Wagner, 2005), the Netherlands (van den Berg and Groot, 1992) and for a group of 24 European countries (Kirmanoğlu and Başlevent, 2012).

The stylized facts emerging from this research are that everywhere unionization is positively related to public sector employment and to establishment size, whereas the impact of sectoral shifts from manufacturing to private services remains unclear and seems to differ across countries. Note, however, that the share of public employment has varied over time in many countries, first increasing with the expansion of the welfare state and then often falling with privatization and deregulation. This means that while the contribution of public employment to (trends in) unionization has been important, this impact has not always served to stabilize union density and may even contribute to further union decline in those countries that cut back the public sector. 


\section{Unionization and changing workforce composition}

Parallel to sectoral changes in the economy, workforce composition has changed in all advanced countries. Usually the employment shares of women, foreign-born workers, atypically employed people, white-collar workers and highly skilled individuals have increased over time, and this is expected to dampen unionization since some of these groups are supposed to have a lower attachment to the labour force, others are said to be more individualistic, and all of them seem to be more difficult (and more costly) to organize (Ebbinghaus et al., 2011; Schnabel and Wagner, 2007; Visser, 2006).

Starting with gender effects, it was often regarded as a stylized fact that women exhibit a lower union density than men. This gap was interpreted as reflecting women's weaker attachment to the labour force which would reduce the benefits of unionization both from the point of view of females and of unions. Over time, however, the gender gap has narrowed and has disappeared in several countries (Calmfors et al., 2001; Ebbinghaus and Visser, 2000). Descriptive evidence provided by Visser (2006) demonstrates that in a number of countries, female union density is now equal to or even higher than male unionization. The comparative analysis of ESS data by Schnabel and Wagner (2007) shows that in eight of the 18 countries investigated, women's density is higher than men's.

Multivariate analyses also indicate that the relationship between gender and unionization is inconclusive and varies among countries. Some cross-sectional studies using data of individuals pooled across countries find a significant negative effect of females on the probability of union membership (Brady, 2007; Kirmanoğlu and Başlevent, 2012). This, however, seems to vanish when controlling for atypical employment (as demonstrated by Ebbinghaus et al., 2011). When analysing countries separately and controlling for fulltime employment status, Schnabel and Wagner (2007) find that the gender variable is statistically insignificant in 11 of the 18 European countries investigated. Union density of women is significantly higher than that of men in the Nordic countries whereas it is still lower in Germany and Italy. That women are less likely to be union members is confirmed for Germany by Goerke and Pannenberg (2007), and for the Netherlands by van den Berg and Grift (2001), while Blanchflower (2007) obtains the same result for the UK, the USA and Canada (but varying estimation coefficients across other countries). In these few countries it thus might make sense for unions to focus their organizing efforts more on women. It is, however, difficult to draw more general conclusions. What seems clear is that in most countries the rising share of women in employment per se should not be a major obstacle to union growth. It may rather be the rise in atypical jobs mostly held by women that poses a problem for unionization.

In most advanced countries, the employment share of standard full-time jobs has fallen in the last decades while atypical employment (such as part-time jobs, fixed-term contracts or temporary agency jobs) has been on the rise. This poses recruitment problems for unions since atypically employed workers usually have weaker ties to their current workplace and are more difficult to recruit and keep as union members. The benefits of unionization may be lower both from the perspective of these workers and of unions, so that the latter have concentrated on organizing full-time workers. Ebbinghaus (2006) and Visser (2006) provide descriptive evidence for several countries that there is 
a considerable gap in unionization between full-time and part-time (or other atypically employed) workers. In a cross-sectional analysis pooling data for individuals from 19 European countries, Ebbinghaus et al. (2011) obtain a highly significant negative relationship between atypical employment and the probability of being unionized whereas Schnabel and Wagner (2007) find very few significant correlations between working full-time and being a union member when using the same data but analyzing countries separately. There are, however, some country studies showing that part-time employment significantly lowers (or full-time employment increases) the probability of union membership (Blanchflower, 2007 for Canada, the USA and the UK). While these findings are from cross-sectional studies, a panel study by Fitzenberger et al. (2011) also shows that working part-time reduces the probability of being unionized in West Germany (but not in East Germany), and the longitudinal analysis by Bodman (1998) finds that the rapid rise in part-time employment had a significant negative impact on unionization in Australia. As atypical employment continues to increase in many countries, this is bad news for the union movement.

Whether a rising share of foreign-born employees dampens unionization is an open question, not least because there is little empirical evidence. Hechter (2004) claims that ethnic heterogeneity resulting from immigration undermines solidarity and hence unionization; this receives some support from the finding by Lee (2005) that international migration is negatively associated with union density in a sample of 16 affluent OECD countries. In contrast, Schnabel and Wagner (2007) find no significant differences in the probability of union membership for native and foreign-born workers in the majority of European countries analyzed, and Brady (2007) even reports that foreign-born workers and net migration are positively related to the likelihood of being a union member.

Since blue-collar workers have been unions' traditional stronghold, the shift in employment towards white-collar work can be expected to reduce union membership and density. White-collar workers are said to have less homogeneous preferences and working conditions and weaker traditions and social customs of unionization. However, Schnabel and Wagner (2007) report that in 2002-2003 only in nine of the 17 European countries investigated was union density lower for white-collar than for blue-collar workers. Moreover, in their multivariate analyses a blue-collar worker dummy proved positive and highly significant in just two countries. More relevant for unionization than the outmoded distinction between blue- and white-collar workers may be the impact of education and qualification, which is investigated in a larger number of studies.

While skilled blue-collar workers are the traditional clientele of unions in most countries, employees with higher education are often assumed to be less willing to unionize, which might pose a problem for unions given rising educational levels in all countries. Better educated employees probably have greater individual bargaining power and thus lesser need for collective voice. However, the empirical evidence is not clear-cut. In a cross-sectional analysis pooling data for individuals from 18 affluent democracies in the late 1990s, Brady (2007) finds that the likelihood of being unionized rises with each level of education, and is higher for skilled manual workers than for other categories of employees such as clerical, manual or unskilled workers. Using pooled data for individuals from 24 European countries from the ESS 2008, Kirmanoğlu and Başlevent (2012) obtain a linear and positive relationship between years of schooling and the probability 
of being a current or former member of a union. With data from the ESS 2002-2003, however, Ebbinghaus et al. (2011) find a curvilinear relationship: with increasing years of education, the probability of being a union member first increases and then decreases at about 15 years of full-time education (with a university degree). In contrast, dummy variables for levels of education are found to be insignificant in the majority of countries by Schnabel and Wagner (2007) when using the same dataset but analysing countries separately. What most studies tend to overlook, however, is the distinction between the private and public sectors. Analysing large individual datasets for the UK, the US and Canada, Blanchflower (2007) demonstrates that more educated workers are less likely to be union members in the private sector and more likely in the public sector.

Workforce composition in all developed countries is also increasingly affected by demographic change. A rising average age of the workforce and cohort replacement effects (in particular, stronger and higher organized cohorts retiring from the workforce) may affect union density if unionization varies in the age dimension. Descriptive evidence for European countries presented by Ebbinghaus (2006) indicates that union density tends to be relatively low among young workers, increases with age, and falls when employees are near retirement. Such a concave relationship is also obtained in several multivariate analyses; but possible explanations (differential need for unions; different free-riding behaviour; different attitudes towards unions; structural and cohort effects) remain vague. With cross-sectional data for individuals, Blanchflower (2007) finds that the probability of being unionized follows an inverted U-shaped pattern in age, maximizing in the mid- to late $40 \mathrm{~s}$ in 34 of the 38 countries investigated. However, such a pattern is statistically significant in only four of the 18 countries analysed by Schnabel and Wagner (2007), which may be because they employ more control variables than Blanchflower (2007). Further studies for individual countries that find a concave relationship include Goerke and Pannenberg (2007) for West Germany and Van Rie et al. (2011) for Denmark and Sweden. Pooling data across countries, Ebbinghaus et al. (2011) and Kirmanoğlu and Başlevent (2012) also obtain a concave age-unionization pattern, whereas Brady (2007) only tests and finds a linear relationship.

From this empirical evidence it seems safe to conclude that younger employees are least likely to be unionized, possibly because they are less interested in joining organizations that they perceive to represent primarily the interests of older workers (Ebbinghaus, 2006) or because unionization is an 'experience good' and there is greater unsatisfied demand for union representation amongst young workers (Bryson et al., 2005). It is difficult to make more definite statements since there are two problems with most of the studies finding a significant relationship between age and unionization. First, the standard methods usually applied when testing for the joint significance of the linear and the quadric term in age do not seem to be fully appropriate (Schnabel and Wagner, 2012). Second, it cannot be ruled out that the age effects detected in these cross-sectional studies are confounded with cohort effects. Addressing that question for the US and the UK, Blanchflower (2007) finds that cohort effects exist but that removing these does not remove the inverted U-shape in age.

Using cohort analysis, Schnabel and Wagner (2008) show that both intra-cohort change and cohort replacement effects have played a roughly equal role in the substantial fall in union density in West Germany. Decomposing age, time and year effects, Böckerman 
and Uusitalo (2006) obtain cohort profiles indicating that a large fraction of the decline in union density in Finland during the 1990s can be attributed to the decrease in density among the cohorts born after the early 1960s. Cohort effects pose serious problems for unions for at least two reasons. First, if older cohorts with high union densities are replaced by young cohorts with low densities (as in Germany and Finland), this implies that average density falls. Second, demographic change in many countries means that future cohorts of potential union members will be smaller than those they replace. This means that even if union density of new cohorts were the same as that of exiting cohorts, the smaller size of new cohorts would result in a fall of total membership. Density would not then fall, but unions would probably face increasing financial problems because of the fixed costs of maintaining a shrinking organization. While unions will not be able to influence demographic change, they must intensify recruitment efforts among young employees. Although such a strategy may be expensive, it would clearly pay off if these cohorts become strongly unionized and if the young employees stay in the union and in the labour market for a long period of time.

Taken as a whole, these results suggest that changes in the composition of the workforce play some role in explaining the changes in unionization observed in the last decades, but the contribution of compositional changes seems smaller than widely believed. Several country studies explicitly investigating the explanatory power of compositional changes underscore this conclusion (Andrews and Naylor, 1994 for the UK; Böckerman and Uusitalo, 2006 for Finland; Charlwood and Haynes, 2008 for New Zealand; Fitzenberger et al., 2011 for Germany; Magnani and Prentice, 2003 for the USA; van den Berg and Grift, 2001 for the Netherlands). These findings imply that de-unionization would have occurred even in the absence of compositional changes.

If such decomposition analyses are right and it is changes in the coefficients estimated rather than compositional changes that seem to drive variations in unionization, then changing attitudes of employees towards unions and changing social values may play a more important role. Stressing individualization processes, for instance, it could be argued that there is a diffusion of more individualistic life styles and post-materialist values (Inglehart, 1977) and that collective and group-specific orientation schemes lose their importance over time (Beck, 1994), which may contribute to union decline. Using data from the ESS 2008, Kirmanoğlu and Başlevent (2012) show that basic personal values are related to (current and former) union membership status. Higher self-transcendence and conservation scores are associated with a greater probability of being a current member whereas higher openness-to-change and self-enhancement scores reduce the likelihood of unionization. Drawing on the 'rising individualism' argument, the authors argue that changing personal values may have been an important factor behind the decline in union membership, but it should be noted that they were only able to conduct a cross-sectional analysis. Further cross-sectional analyses show that individual union membership accompanies pro-union attitudes, such as Visser (2002) for the Netherlands and Schnabel and Wagner (2007) for most countries in Western Europe (but not for some post-communist countries in Eastern Europe). Biebeler and Lesch (2007) show that on average the attitudes of West German workers have (slightly) changed over the last 20 years towards a stronger emphasis on self-responsibility and economic freedom, and that a composite index of economic freedom is negatively correlated with 
union membership. What is needed, however, are panel analyses showing that there have been substantial changes in individual employees' attitudes and values over time and that this has indeed affected unionization. Since the empirical evidence on this point is very limited, 'it must remain a matter of speculation whether employees are less motivated by collective values than, say, one or two generations ago' (Calmfors et al., 2001: 31) and whether this has really contributed to falling union membership.

\section{Unionization, institutional settings and globalization}

There exist a number of institutional explanations that mainly focus on cross-national variations in unionization but which also can be used to explain union growth and decline over time. Variables emphasized in this literature dominated by political scientists and sociologists (Brady, 2007; Ebbinghaus and Visser, 1999; Scruggs and Lange, 2002; Western, 1997) include union-administered unemployment insurance, closed-shop arrangements and union access to the workplace as well as structures of collective bargaining. In a wider sense, changes in the economic environment induced or favoured by changes in government regulation, such as increasing globalization, also fall into this category.

One institutional variable that has been found strongly to affect unionization in most cross-national studies is the provision or administration of unemployment insurance by trade unions. This 'Ghent system' comes in two variants: either in the form of voluntary unemployment insurance funds set up by the unions and subsidized by the state, as in Sweden, Denmark and Finland, or as a compulsory unemployment insurance system partly administered by union officials, as in Belgium. Although union-run unemployment insurance may not be a 'selective incentive' as defined by Olson (1965), since union membership is usually not compulsory for those insured and there exist alternatives options of acquiring insurance, the important role of union officials in the provision of unemployment benefits and the regular contact with the union during spells of unemployment are said to motivate workers strongly to join unions and remain members when unemployed (for details, see Holmlund and Lundborg, 1999; Scruggs, 2002; Van Rie et al., 2011).

The high union density rates in the three Nordic countries and Belgium are therefore often attributed to positive effects of their Ghent systems. It is striking that among the 25 countries listed in Table 1, density is indeed highest in Finland, Sweden and Denmark, with Belgium ranked fifth in 2010. A number of multivariate cross-sectional studies show that Ghent system countries enjoy a substantial advantage in unionization (Brandl, 2009; Ebbinghaus and Visser, 1999; Wallerstein and Western, 2000) and that individual employees in these countries are much more likely to be unionized, ceteris paribus (Brady, 2007; Ebbinghaus et al., 2011).

A similar picture emerges when long-term changes in union density are analysed. It may be no coincidence that in the period 1980 to 2010 density has remained most stable in Finland and Belgium (among the 24 countries listed in Table 1). When the percentage point change in union density between 1980 and 2010 is regressed on the starting value of density in 1980 and a dummy variable that takes the value of 1 for the four Ghent system countries, the following estimation results emerge $\left(N=24, R^{2}=0.596, t\right.$-statistics in parentheses): 
$\Delta$ union density $=4.27-0.52$ union density in $1980+27.04$ Ghent dummy (0.93) (-4.90)

The Ghent dummy and the starting level of union density explain almost 60 percent of the variance in changing union density (whereas the density level on its own would explain less than 11\%). Taken at face value, the coefficient of the Ghent dummy variable implies that the decline in union density over the period 1980 to 2010 was 27 percentage points lower in countries with a Ghent system. A number of other studies (Blaschke, 2000; Checchi and Lucifora, 2002; Ebbinghaus and Visser, 1999; Scruggs, 2002) confirm that the Ghent system has been associated with higher growth rates in density in various periods. Longitudinal analyses by Checchi and Visser (2005) and Visser (2006) further indicate that while in general unemployment has a negative impact on union density in the short and long run, its impact is positive in Ghent countries.

Given this impressive empirical evidence on the importance of Ghent systems for promoting and sustaining high levels of union density, it might be asked whether the Ghent system is a possible cure for declining unionization in other countries. Pointing out that the majority of former countries with Ghent systems replaced these by mandatory insurance many decades ago, Van Rie et al. (2011) consider it highly unlikely that others countries will adopt a Ghent system. Moreover, they argue that the Belgian institutional set-up only stimulates union membership among particular groups and that the Ghent systems in the Nordic countries have been subject to erosion as unemployment insurance has become more costly and less generous (Lind, 2009). More specifically, Böckerman and Uusitalo (2006) opine that the fall in union density in Finland since the 1990s mainly reflects the erosion of the Ghent system with the emergence of an independent unemployment insurance fund not requiring union membership. Kjellberg (2011) argues that the substantial increase in fees for union unemployment funds initiated by the centre-right government in 2007 is the main reason for the unprecedented decline in unionization in Sweden in recent years. The stabilizing effect of Ghent systems on union density should thus not be taken for granted and will most probably continue to be restricted to a small number of countries.

Another institutional variable that seems to play an important role for unionization is unions' access to or presence at the workplace. This can be expected to increase union membership in various ways, for instance by facilitating unions' recruitment efforts, enabling them to represent visibly the interests of the workforce and creating social custom and reputation effects (Schnabel and Wagner, 2007). Following Ebbinghaus and Visser (1999), several cross-national analyses have included indicators of the degree of institutionalized union access to the workplace in. Empirical analyses usually find that union access to the workplace significantly increases individuals' probability of being a union member (Brady, 2007), that it is associated with higher union density (Ebbinghaus and Visser, 1999) and that it also positively affects changes in density (Checchi and Lucifora, 2002; Checchi and Visser, 2005; Visser, 2002). ${ }^{2}$ Studies focusing on the actual presence of a union at the workplace rather than on its institutionalized access point in the same direction. In a cross-sectional analysis pooling data for individuals from 19 European countries, Ebbinghaus et al. (2011) obtain a highly significant positive relationship 
between the presence of a union at the workplace and the probability of being unionized. When using the same data but analysing countries separately, Schnabel and Wagner (2007) find union presence to be a strong predictor of union membership in almost all countries. The empirical evidence suggests that unions which want to increase or stabilize their membership should try to increase (or at least maintain) their presence at the workplace, even if this might be opposed by employers and might become more difficult and more expensive as workplaces become smaller.

Unionization may also depend on a country's structure of collective bargaining, with more centralized bargaining usually considered conducive to higher density (Scruggs and Lange, 2002). One reason is that bargaining centralization can reduce employers' incentives to eliminate unions from their workplaces (because these now tend to interfere less in workplace management and local wage-setting). Centralized bargaining also lowers transaction costs, helps to solve the latent conflict between capital and labour and can bring macroeconomic benefits, so that governments may have an interest in maintaining strong unions. On the other hand, bargaining centralization may make it easier for employees to free-ride on collective agreements without being members, in particular when these are extended to non-unionized employees and workplaces. The theoretical relationship between centralization and unionization is thus open, and the empirical evidence is equally mixed. Some cross-national studies report a positive relationship between unionization and bargaining centralization (Western, 1997) while others obtain findings that are insignificant and/or difficult to interpret (Blaschke, 2000; Brady, 2007, Sano and Williamson, 2008; Scruggs and Lange, 2002). Panel studies for 14 European countries by Visser (2002) and Checchi and Visser (2005) suggest that centralization had a significant positive impact on unionization in the period 1950 to 1996-1997, whereas Checchi and Lucifora (2002) find that the bargaining centralization/coordination variable sometimes loses statistical significance and changes signs in their panel estimates for 13 countries between 1960 and 2000. Given these conflicting results it would be premature to predict that the recent trend towards decentralization of collective bargaining in several countries will automatically bring large-scale deunionization. While there may be good reasons for unions to oppose decentralization (for instance, higher transaction costs), membership considerations alone do not necessarily suggest such a strategy.

In comparison with some of the institutional variables discussed above, the empirical evidence concerning the impact of globalization on unionization is more limited. Although increasing national openness to trade, financial flows and foreign direct investment (FDI) is often thought to undermine unionization by weakening unions' bargaining power and thus their attractiveness to employees, unions may also benefit from globalization, for instance by serving as vehicles of insurance against volatile global market forces (Brady, 2007; Scruggs and Lange, 2002). While the theoretical relationship between globalization and (de-)unionization is thus open, the empirical evidence has become more and more univocal. Weak evidence for globalization effects is only provided by Western (1997) who finds that trade openness increased the likelihood that an advanced country would experience a decline in unionization in the 1980s, and by Blaschke (2000) who reports a small dampening effect of trade openness on changes in union density in some of her specifications for the period 1970 to 1995. 
In contrast, Scruggs and Lange (2002), in an analysis of 16 advanced countries in the period 1964 to 1994, show that controlling for cyclical and demographic features there are no robust significant relationships between changes in union density and increasing financial market openness, FDI flows or increased trade flows. Similarly, Sano and Williamson (2008) find no robust impact of FDI and trade openness in a pooled sample of 18 OECD countries from 1980 to 2005, and for a panel of 14 European countries Checchi and Visser (2005) report that changes in union density are unaffected by proxies for increased globalization. In a multilevel analysis for a group of 18 affluent democracies in the late 1990s, Brady (2007) finds that net trade and investment do not significantly affect unionization (see also Martin and Brady, 2007). Finally, an analysis of manufacturing industries in the USA by Magnani and Prentice (2003) concludes that globalization as visible in international and domestic market competition cannot explain the bulk of the substantial decline in unionization in the period 1973 to 1994 . This empirical evidence stands in stark contrast to the widespread impression that globalization has undermined employees' likelihood of being union members. It implies that unionization has neither been severely affected by institutional changes deregulating certain markets (in particular financial markets) nor can it be expected to benefit much from the re-regulation of these markets. ${ }^{3}$

\section{Conclusions}

This article has shed some light on what we know and do not know about (trends in) unionization and its determinants in advanced countries. It has shown that there are relatively few robust stylized facts, and that some seemingly obvious explanations for the decline in unionization over the last decades do not hold on closer scrutiny. In particular, the following perceptions often found in the general public have been debunked as myths. First, unions are not about to vanish everywhere. While density has indeed fallen in almost all advanced countries, it has remained high in some European countries (in particular the Nordic countries). Second, union growth and decline are not mainly outcomes of changes in the sectoral structure of the economy and the composition of the workforce. Third, economic globalization in recent decades does not seem to have substantially undermined unionization. Fourth, the relationship between centralization of collective bargaining and unionization is open both theoretically and empirically; bargaining decentralization thus does not necessarily imply deunionization.

That said, the empirical literature does point to some regularities that may indeed be interpreted as stylized facts. First, union density and trends in unionization vary considerably across Western countries, with no clear signs of convergence. Second, unionadministered unemployment insurance is associated with higher union density and smaller falls in density over time. Third, union access to, and presence at, the workplace play an important, positive role for (changes in) unionization. Fourth, unionization is related to the business cycle, with union growth being procyclical. In many countries a rise in unemployment tends to reduce union growth and density (but in countries with a Ghent system the reverse is the case). Fifth, in almost all countries unionization is positively related to public sector employment and to establishment size. Sixth, younger 
employees are generally less likely to be unionized (but it is less clear whether the probability of being unionized always follows an inverted U-shaped pattern in age).

Of course, this review of the empirical evidence can only provide a crude picture of major factors that seem to play a role for unionization, neglecting country-specific conditions, national traditions, historical influences and differences between the Anglo-Saxon world and European welfare states (Schmitt and Mitukiewicz, 2012) that may also be relevant. Empirical studies have not always been able to disentangle the effects of parallel and related developments (such as sectoral changes and changes in the composition of the workforce), to take full account of interactions between variables (such as institutions, business cycle effects and personal characteristics), and to establish causation rather than just correlation between variables. The empirical evidence also does not enable us to discriminate between alternative (but often related) theories from various disciplines. For these and other reasons, this review does not claim to provide a general explanation of union growth and decline. ${ }^{4}$ Nevertheless, the empirical regularities identified can be used to assess how unions will be affected by recent economic and social trends present in most countries and to speculate whether they will be able to cope with these challenges.

In contrast to widespread perceptions, some trends like economic globalization and the rising proportions of women, white-collar workers and highly educated employees in the workforce do not seem to have impeded union membership and density, and probably they will not pose serious problems for unions in the future. Similarly, given the mixed empirical evidence it seems premature to predict that the trend towards bargaining decentralization in many countries will go along with large-scale deunionization. Given the lack of long-term empirical evidence it also remains an open question whether changes in social values, rising individualism and changing attitudes of employees towards unions have affected or will affect unionization negatively.

More important and empirically founded challenges for unions in most advanced countries seem to be demographic change (in particular, stronger and higher organized cohorts retiring from the workforce) and the difficulty in recruiting young employees. A major problem for the unions may also be that the employment share of the public sector, which is still a union stronghold, has been falling and may fall further because of privatization, subcontracting and the shrinking of the welfare state. Another challenge comes from the rise in atypical employment visible in most countries, since several studies indicate that part-timers and other atypically employed workers are more difficult to organize than other workers with stronger attachments to the labour market. Since unionization is positively correlated with firm size, the decline in the average size of firms in many countries may also undermine unionization, in particular if a reduction in union presence at the workplace accompanies this. Finally, in countries with a Ghent system, its erosion poses a serious threat to union membership and density.

Some of these trends working against unionization (such as demographic change and the decline in average firm size) cannot be influenced by the unions. Some others, however, may at least be dampened if the labour movement can exert political influence and successfully oppose further privatization, deregulation and reform of unemployment insurance systems. In addition, there are still large gaps in unionization that can be filled by effective union organization. Although a discussion of union recruitment and renewal 
strategies (Frege and Kelly, 2004; Gall, 2009) is beyond the scope of this article, it seems obvious that recruitment efforts should be (more) focused on young and atypically employed workers (in some countries also on women), that upholding or increasing union presence at the workplace is crucial for keeping and winning union members and that in general unions should probably more open up to new social interests (Ebbinghaus, 2006).

While recent reports of 'union revitalization', mainly from Anglo-Saxon countries (Gall, 2009) should not be overemphasized, unions in many countries, particularly in Western Europe, still have some chance to stabilize membership and density, not least because they are embedded in social, economic and political structures that help sustain them (Bryson et al., 2011). For decades, public perception of unions has been that 'they're going out like a dinosaur', as expressed by Bob Dylan in his song 'Union Sundown' (released in 1983!). However, unions are still alive and reversals in union fortunes have happened in the past in many countries, so that it may be premature to relegate them to a museum of extinct species.

\section{Acknowledgements}

I would like to thank Annette van den Berg as well as two referees and the journal editor for helpful comments and suggestions. A longer version of this article can be found at http://ftp.iza.org/ dp6792.pdf.

\section{Funding}

This research received no specific grant from any funding agency in the public, commercial, or not-for-profit sectors.

\section{Notes}

1. Space constraints preclude us from discussing the role of some other variables that might be associated with unionization, but which have been found to affect union membership and density in an unstable way across countries and time periods. These include strikes (Calmfors et al., 2001; Checchi and Visser, 2005; Western, 1997), political attitudes (Kirmanoğlu and Başlevent, 2012; Schnabel and Wagner, 2007), the broad national political environment (Schmitt and Mitukiewicz, 2012) and government composition (Brady, 2007; Checchi and Visser, 2005; Scruggs and Lange, 2002; Western 1997), management opposition (Flanagan, 2005; Freeman and Medoff, 1984), social capital (Ebbinghaus et al., 2011) as well as employees' risk aversion (Goerke and Pannenberg, 2012).

2. However, statutory employee representation and mandatory works councils do not necessarily exert a positive influence on unionization (Blaschke, 2000; Goerke and Pannenberg, 2007), and closed-shop practices that used to be common in Ireland and the UK do not always strengthen aggregate union density and density growth (Blaschke, 2000; Ebbinghaus and Visser, 1999).

3. That globalization cannot be the main culprit for deunionization is also suggested by the descriptive evidence reported in Table 1, which shows that in several countries union density has started to decline already in the 1960s, clearly prior to economic globalization, and that union density across countries has diverged over time (whereas globalization should have affected countries in a largely similar way).

4. Another reason for modesty is that we know little about the actual process of joining or leaving a union, which very few studies have investigated (Van Rij and Daalder, 1997; Visser, 2002; Waddington and Whitston, 1997). 


\section{References}

Andrews M and Naylor R (1994) Declining union density in the 1980s: What do panel data tell us? British Journal of Industrial Relations 32: 413-431.

Ashenfelter O and Pencavel JH (1969) American trade union growth: 1900-1960. Quarterly Journal of Economics 83: 434-448.

Bain GS and Elias P (1985) Trade union membership in Great Britain: An individual-level analysis. British Journal of Industrial Relations 23: 71-92.

Bain GS and Elsheikh F (1976) Union Growth and the Business Cycle: An Econometric Analysis. Oxford: Blackwell.

Beck U (1994) The debate on the individualization theory in today's sociology in Germany. Soziologie - Journal of the Deutsche Gesellschaft für Soziologie, Special Edition 3: 191-200.

Biebeler H and Lesch H (2007) Zwischen Mitgliedererosion und Ansehensverlust: Die deutschen Gewerkschaften im Umbruch. Industrielle Beziehungen 14: 133-153.

Blanchflower DG (2007) International patterns of union membership. British Journal of Industrial Relations 45: 1-28.

Blanchflower DG and Bryson A (2009) Trade union decline and the economics of the workplace. In:Brown W, Bryson A, Forth J and Whitfield K (eds) The Evolution of the Modern Workplace. Cambridge: Cambridge University Press, pp. 48-73.

Blaschke S (2000) Union density and European integration. European Journal of Industrial Relations 6: 217-236.

Bodman PM (1998) Trade union amalgamations, openness and the decline in Australian trade union membership. Australian Bulletin of Labour 24: 18-45.

Böckerman P and Uusitalo R (2006) Erosion of the Ghent System and union membership decline: Lessons from Finland. British Journal of Industrial Relations 44: 283-303.

Borland J and Ouliaris S (1994) The determinants of Australian trade union membership. Journal of Applied Econometrics 9: 453-468.

Brady D (2007) Institutional, economic, or solidaristic? Assessing explanations for unionization across affluent democracies. Work and Occupations 34: 67-101.

Brandl B (2009) Bayesian model averaging and model selection: Two sides of the same coin when identifying the determinants of trade union density? Central European Journal of Operations Research 17: 13-29.

Bryson A, Ebbinghaus B and Visser J (2011) Introduction: Causes, consequences and cures of union decline. European Journal of Industrial Relations 17: 97-105.

Bryson A, Gomez R, Gunderson M and Meltz N (2005) Youth-adult differences in the demand for unionization: Are American, British, and Canadian workers all that different? Journal of Labor Research 26: 155-167.

Calmfors L, Booth A, Burda M, Checchi D, Naylor R and Visser J (2001) The future of collective bargaining in Europe. In:Boeri T, Brugiavini A and Calmfors L (eds) The Role of Unions in the Twenty-First Century. Oxford: Oxford University Press, pp. 1-155.

Carruth A and Disney R (1988) Where have two million trade union members gone? Economica 55: $1-19$.

Carruth A and Schnabel C (1990) Empirical modelling of trade union growth in Germany, 19561986: Traditional versus cointegration and error correction methods. Weltwirtschaftliches Archiv 126: 326-346.

Charlwood A and Haynes P (2008) Union membership decline in New Zealand 1990-2002. Journal of Industrial Relations 50: 87-110.

Checchi D and Corneo G (2000) Trade union membership: Theories and evidence for Italy. Lavoro e relazioni industriali 7 : 151-186. 
Checchi D and Lucifora C (2002) Unions and labour market institutions in Europe. Economic Policy 17: 362-408.

Checchi D and Visser J (2005) Pattern persistence in European trade union density: A longitudinal analysis 1950-1996. European Sociological Review 21: 1-21.

Ebbinghaus B (2006) Trade union movements in post-industrial welfare states. Opening up to new social interests? In:Armingeon K and Bonoli G (eds) The Politics of Post-Industrial Welfare States. London: Routledge, pp. 123-142.

Ebbinghaus B, Göbel C and Koos S (2011) Social capital, 'Ghent' and workplace contexts matter: Comparing union membership in Europe. European Journal of Industrial Relations 17: $107-124$.

Ebbinghaus B and Visser J (1999) When institutions matter - Union growth and decline in Western Europe, 1950-1995. European Sociological Review 15: 135-158.

Ebbinghaus B and Visser J (2000) Trade Unions in Western Europe since 1945. Basingstoke: Macmillan.

Farber HS and Western B (2001) Accounting for the decline of unions in the private sector, 1973-1998. Journal of Labor Research 22: 459-485.

Fitzenberger B, Kohn K and Wang Q (2011) The erosion of union membership in Germany: Determinants, densities, decompositions. Journal of Population Economics 24: 141-165.

Flanagan RJ (2005) Has management strangled U.S. unions? Journal of Labor Research 26: 33-63. Freeman RB and Medoff JL (1984) What Do Unions Do? New York: Basic Books.

Frege C and Kelly J (eds) (2004) Varieties of Unionism: Strategies for Union Revitalization in a Globalizing Economy. Oxford: Oxford University Press.

Gall G (ed.) (2009) Union Revitalisation in Advanced Economies: Assessing the Contribution of Union Organising. Basingstoke: Palgrave Macmillan.

Goerke L and Pannenberg M (2007) Trade union membership and works councils in West Germany. Industrielle Beziehungen 14: 154-175.

Goerke L and Pannenberg M (2012) Risk aversion and trade union membership. Scandinavian Journal of Economics 114: 275-295.

Hechter M (2004) From class to culture. American Journal of Sociology 110: 400-445.

Holmlund B and Lundborg P (1999) Wage bargaining, union membership, and the organization of unemployment insurance. Labour Economics 6, 397-415.

Inglehart R (1977) The Silent Revolution: Changing Values and Political Styles among Western Publics. Princeton, NJ: Princeton University Press.

Kirmanoğlu H and Başlevent C (2012) Using basic personal values to test theories of union membership. Socio-Economic Review 10: 683-703.

Kjellberg A (2011) The decline in Swedish union density since 2007. Nordic Journal of Working Life Studies 1: 67-93.

Lee CS (2005) International migration, deindustrialization and union decline in 16 affluent OECD countries, 1962-1997. Social Forces 84: 71-88.

Lind J (2009) The end of the Ghent system as trade union recruitment machinery? Industrial Relations Journal 40: 510-523.

Magnani E and Prentice D (2003) Did globalization reduce unionization? Evidence from US manufacturing. Labour Economics 10: 705-726.

Martin ND and Brady D (2007) Workers of the less developed world unite? A multilevel analysis of unionization in less developed countries. American Sociological Review 72: 562-584.

Olson M (1965) The Logic of Collective Action. Cambridge, MA: Harvard University Press.

Polachek SW (2004) What can we learn about the decline in U.S. union membership from international data? In:Wunnava PV (ed.) The Changing Role of Unions: New Forms of Representation. New York: ME Sharpe, pp. 362-377. 
Riley NM (1997) Determinants of union membership: A review. Labour 11: 265-301.

Sano J and Williamson JB (2008) Factors affecting union decline in 18 OECD countries and their implications for labor movement reform. International Journal of Comparative Sociology 49: 479-500.

Schmitt J and Mitukiewicz A (2012) Politics matter: Changes in unionization rates in rich countries, 1960-2010. Industrial Relations Journal 43: 260-280.

Schnabel C (2003) Determinants of trade union membership. In:Addison JT and Schnabel C (eds) International Handbook of Trade Unions. Cheltenham: Edward Elgar, pp. 13-43.

Schnabel C and Wagner J (2005) Determinants of trade union membership in West Germany: Evidence from micro data, 1980-2000. Socio-Economic Review 3: 1-24.

Schnabel C and Wagner J (2007) Union density and determinants of union membership in 18 EU countries: Evidence from micro data, 2002/03. Industrial Relations Journal 38: 5-32.

Schnabel C and Wagner J (2008) The aging of the unions in West Germany, 1980-2006. Journal of Economics and Statistics 228: 497-511.

Schnabel C and Wagner J (2012) With or without U? Testing the hypothesis of an inverted U-shaped union membership-age relationship. Contemporary Economics 6: 28-34.

Scruggs L (2002) The Ghent system and union membership in Europe, 1970-1996. Political Research Quarterly 55: 275-297.

Scruggs L and Lange P (2002) Where have all the members gone? Globalization, institutions and union density. Journal of Politics 64: 126-153.

Van den Berg A and Grift Y (2001) Dutch trade union membership 1979-1995. Applied Economics 33: 1233-1242.

Van den Berg A and Groot W (1992) Union membership in the Netherlands: A cross-sectional analysis. Empirical Economics 17: 537-564.

Van Ours JC (1992) Union growth in the Netherlands 1961-1989. Applied Economics 24: 1059-1066.

Van Rie T, Marx I and Horemans J (2011) Ghent revisited: Unemployment insurance and union membership in Belgium and the Nordic countries. European Journal of Industrial Relations 17: 125-139.

Van Rij C and Daalder A (1997) The business cycle theory and individual unionization decisions: A comparison of macro and micro influences on union membership. In:Sverke M (ed.) The Future of Trade Unionism. Aldershot: Ashgate, pp. 235-248.

Visser J (2002) Why fewer workers join unions in Europe. British Journal of Industrial Relations 40: 403-430.

Visser J (2006) Union membership statistics in 24 countries. Monthly Labor Review 129: 38-49.

Visser J (2011) ICTWSS: Database on institutional characteristics of trade unions, wage setting, state intervention and social pacts in 34 countries between 1960 and 2007. Available at: http:// www.uva-aias.net/208.

Waddington J and Whitston C (1997) Why do people join unions in a period of membership decline? British Journal of Industrial Relations 35: 515-546.

Wallerstein M and Western B (2000) Unions in decline? What has changed and why. Annual Review of Political Science 3: 355-377.

Western B (1997) Between Class and Market-Postwar Unionization in the Capitalist Democracies. Princeton, NJ: Princeton University Press.

\section{Author biography}

Claus Schnabel is Professor of Labour Economics at the University of Erlangen-Nürnberg, Germany, and heads the Labor and Socio-Economic Research Center (LASER). 